\title{
Deciphering cork formation in Quercus suber
}

\author{
Jorge AP Paiva ${ }^{1 *}$, Pedro Fevereiro ${ }^{2}$, Pedro Marques ${ }^{3}$, José Carlos Rodrigues ${ }^{4}$, Grégoire Le Provost $^{5}$, \\ Christophe Plomion ${ }^{5}$, Jacqueline Grima-Pettenati ${ }^{6}$, Olivier Bouchez ${ }^{7}$, Christophe Klopp ${ }^{8}$, Hélène Berges ${ }^{9}$, \\ José Graça ${ }^{10}$ \\ From IUFRO Tree Biotechnology Conference 2011: From Genomes to Integration and Delivery \\ Arraial d Ajuda, Bahia, Brazil. 26 June - 2 July 2011
}

The family of Fagaceae, comprises about 900 species, among them the best-known group of this family is the oaks, genus Quercus, that are commonly used as timber or for cork production. Cork is produced by Q. suber, an evergreen oak with major economic and environmental importance for Mediterranean region, in particular for Portugal that is the leading producer of this material.

Besides, the economic importance of cork production and cork manufacturing, little attention has been paid to the molecular mechanisms underlying wood and cork formation as well as cork quality. To overcome this constraint, an international partnership (SuberGene) was established 2008, involving Portuguese and French research institutions and one Producer's Association organization (FJLF). The main driving force of this partnership is to join efforts and complementary skills to unravel to the molecular mechanisms underlying cork formation and decipher the structural polymorphisms and regulation network that determine cork quality.

A non-normalized cDNA library of developing phellem (DP) was produced and 5,000 clones were sequence both ends using Sanger technology. More than 6500 good quality ESTs were deposit at GeneBank. DP transcriptome was also assessed by pirosequencing (454FLX Titanium, Roche) generating more than 200,000 reads. Sequencing data $(238,911$ ESTs) data were assembled into 69,559 contigs. Suberin biosynthesis genes such as Glycerol-3-phosphate acyltransferase and Omega-hydroxypalmitate Oferuloyl transferase are among the more expressed genes in DP tissues. More than 2,800 putative SNPs were detected in 1,121 contigs. As a complementary strategy,

\footnotetext{
* Correspondence: jorge@itqb.unl.pt

'Instituto de Investigação Científica Tropical (IICT), FLOR-Centro de Florestas e dos Produtos Florestais, Tapada da Ajuda, 1349-018 Lisboa, Portugal \& Instituto de Biologia Experimental e Tecnológica, Apartado 12, 2781-901 Oeiras, Portugal

Full list of author information is available at the end of the article
}

the proteome of DP are being assessed, by 2D-PAGE, and mass spectroscopy. In order to get more information about the gene structure of genes related with the suberisation of cork cell-wall, one Q. suber BAC library have been constructed, and are being characterized. Clones harboring genes of interest were identified by screening highdensity filters of this BAC library.

These resources provides us with valuable tools to study the nature of the molecular machinery involved in cork formation, and most importantly with the players involved in the variability of cork characteristics. Future ongoing approaches and the impact of these finding will be discussed.

\section{Acknowledgments \\ The authors would like to thank the valuable contribution of actual and former members of the involved groups and institutions: Susana Araújo ${ }^{1}$, Victor Carocha', Cláudio Capitão², Clara Graça², Joana Amado², Céline Lalanne ${ }^{5}$, Nathalie Ladouce ${ }^{6}$, Céline Noirot $^{8}$, Elisa Prat ${ }^{9}$, Sonia Vautrin ${ }^{9}$, Joelle Fourment? \\ This work was partially supported by FCT (Portugal) (PTDC/AGR-GPL/101785/ 2008). Authors also acknowledged FJLF that provided the plant material necessary for this work.}

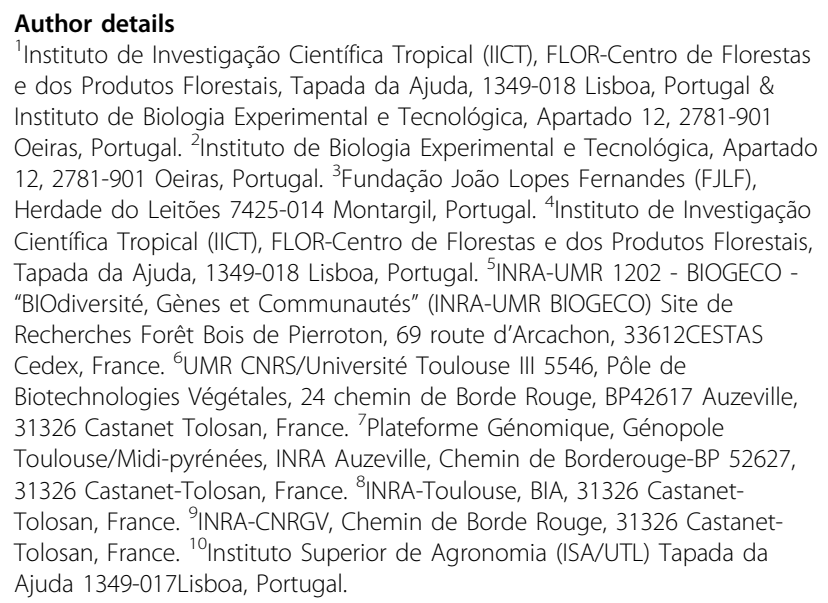



and take full advantage of:

- Convenient online submission

- Thorough peer review

- No space constraints or color figure charges

- Immediate publication on acceptance

- Inclusion in PubMed, CAS, Scopus and Google Scholar

- Research which is freely available for redistribution 